\title{
Marked Inhibition of Cellular Proliferation in the Normal Human Esophageal Epithelial Cells and Human Esophageal Squamous Cancer Cells in Culture by Carotenoids: Role for Prevention and Early Treatment of Esophageal Cancer
}

\author{
Sudhir Dutta*, Balarama Krishna Surapaneni², Agam Bansal ${ }^{3}$
}

\begin{abstract}
Background: Globally Esophageal cancer is a common cancer arising from human esophageal mucosal tissue. Epidemiological studies suggest inverse correlation between carotenoid intake and incident risk of this devastating malignancy. Methods: In an effort to examine the modulatory role of carotenoids in human esophageal carcinogenesis at a cellular level, we examined the effects of $\alpha$-carotene and $\beta$-carotenes, on cell proliferation and DNA synthesis in human esophageal epithelial (HEE) cells and human esophageal squamous cancer (HESC) cells in in-vitro cultures. HEE and HESC cells were incubated with different concentrations of $\alpha$ - and $\beta$-carotenes both individually and in combination. Results: Both Carotenes significantly inhibited $(\mathrm{p}<0.05)$ cellular proliferation and decreased DNA synthesis in HEE and HESC cells. The effect of $\alpha$ - and $\beta$-carotene together on DNA synthesis in HEE and HESC cells was significantly greater than either carotenoid alone, suggesting a synergistic effect. Greater magnitude of cellular inhibition of DNA synthesis was observed on HEE cells than HESC cells. Conclusion: Our results suggest that a combination of $\alpha$-and $\beta$-carotene may provide a novel strategy for prevention and treatment of esophageal and upper aero digestive tract cancer in humans.
\end{abstract}

Keywords: Carotenoids- human esophageal epithelial cells- esophageal squamous cell carcinoma

Asian Pac J Cancer Prev, 19 (11), 3251-3256

\section{Introduction}

Worldwide esophageal cancer is the eighth most common cancer and the sixth most common cause of death from cancer (Kamangar et al., 2006). In the United States, an estimated 16,940 cases of esophageal cancer will be diagnosed in 2017 and 15,690 deaths are expected to occur from it (Siegel et al., 2017). Esophageal cancer is associated with a dismal prognosis with 5-year survival rates of about 18\% (Ruol et al., 2009).

Esophageal squamous cell cancer accounts for $90 \%$ of the total incident cases of esophageal cancer each year (Gholipour et al., 2008). Tobacco smoking and alcohol consumption have been established as strong risk factors for esophageal squamous cell cancer (Freedman et al., 2007). Furthermore, intake of lamb meat, fried, barbecued, or boiled red meat, salted meat, (De et al., 2012) and diets low in fruits and vegetables leading to micronutrient deficiency may also appear to be risk factors for esophageal squamous cell cancer (Glade, 1999). It has been suggested based on available evidence that carotenoids exert a protective effect against head and neck cancer (Mayne et al., 2001), oral cancer (Garewal, 1993), skin cancer (Greenberg et al., 1990), lung cancer (Greenwald, 2003) and various other malignancies. A meta analysis suggested that a higher intake of carotenoids (beta-carotene, alpha- carotene, lycopene, beta-cryptoxanthin, lutein, and zeaxanthin) is associated with lower risk of esophageal cancer (Xiao-Xiao et al., 2013).

In the early $1980 \mathrm{~s}$, it was proposed that $\beta$ carotene might reduce the risk of cancer (Peto et al., 1981). Since then, several in vitro studies have evaluated the role of carotenes in preventing carcinogenesis. Most of the recent in vitro studies have focused on the anti-carcinogenic mechanism of $\beta$-carotene on lung, liver and blood cells (Al-Wadei et al., 2009; Sacha et al., 2011; Sampaio et al., 2007). Certain animal studies have shown that $\alpha$-carotene possesses higher activity than $\beta$-carotene in suppressing carcinogenesis in the liver, lung, skin, and colon (Murakoshi et al., 1992; Narisawa et al., 1996). There are few studies that have focused on the effect of carotenes on human esophageal squamous cancer cells but 
to the best of our knowledge, there has not been any study evaluating the effect of carotenoids, a- and b-carotene over the normal human esophageal epithelial cells.

The purpose of the present study was to investigate the effects of $\alpha$-carotene, $\beta$-carotene alone and in combination on cellular proliferation and DNA synthesis of normal human esophageal epithelial (HEE) cells and human esophageal squamous cancer (HESC) cells in order to provide a scientific basis for consideration of prevention and treatment of esophageal cancer and its precursor lesions.

\section{Materials and Methods}

\section{Reagents}

$\alpha$-carotene and $\beta$-carotene were purchased from Sigma Chemical Co., St. Louis, MO, USA. The carotenes were dissolved in ethanol and then diluted to a final concentration of $0.1 \%$, a concentration that was nontoxic to the cells (Ellis et al., 2009).

\section{Cell Culture}

HEE cell line was developed from esophageal mucosal explants obtained as a part of our immediate autopsy program (with a postmortem interval of $12 \mathrm{~h}$ or less) using a modification of the method described previously by Resau et al., (1990). Briefly, cells were harvested from mucosal explants ( 1 to $5 \mathrm{~mm}$ ) by trypsinization for 24-48 h. Sixty percent of all mucosal explant cultures yielded viable epithelial cell cultures. Cells were cultured at $37^{\circ} \mathrm{C}$ in a humidified atmosphere containing $5 \%$ $\mathrm{CO}_{2}$ and routinely maintained in keratinocyte growth medium (KGM) supplemented with murine epidermal growth factor (EGF, $10 \mathrm{ng} / \mathrm{mL}$ ), bovine insulin $5 \mathrm{mg} / \mathrm{mL}$, hydrocortisone $0.5 \mathrm{mg} / \mathrm{mL}$, bovine pituitary extract $0.01 \%$ (vol/vol), and gentamicin and amphotericin mixture 50 $\mu \mathrm{g} / \mathrm{mL}$ each. HEE cells were characterized by cytokeratin 8 and 19 positivity and vimentin negativity tested by immunofluorescence as described by Resau et al., (1990) These cells grow as a monolayer of polygonal cells and form desmosomal connections. Furthermore, these cells co-express keratin and vitamin intermediate filaments and exhibit an actin filament pattern characteristic of epithelial cells. The cells have a doubling time of approximately 48 $\mathrm{h}$, require more than one week to reach confluence, and can be passaged up to 20-30 times. In the present study, all experiments were performed with cells at passage number $10-15$.

HESC mucosa was obtained by pinch biopsy from seven male subjects with ESCC (age range: 45-65 years) undergoing upper endoscopy. The HESC cell line was developed from the esophageal mucosa explants by a modification of the method described above for HEE cells. HESC cells were characterized by standard morphological and cytological features of cultured malignant cells including high nucleus to cytoplasmic ratio, multi-nucleated cells and short doubling time.

\section{Cell Proliferation Assay}

HEE and HESC cells were seeded at an initial density of 100,000-200,000 cells/well in 24-well plates in KGM containing all the supplements and allowed to grow for $24 \mathrm{~h}$. Cells were then switched to culture medium with or without various concentrations of $\alpha$-carotene, $\beta$-carotene or a combination of $\alpha$ - and $\beta$-carotene, respectively (5-10 $\mu \mathrm{M})$. Cultured Epithelial Cells in triplicate wells were counted on Day 1 and every $48 \mathrm{~h}$ using a hemocytometer for up to 15 days for HEE cells and 11 days for HESC cells. Fresh culture media with additives were replenished every $48 \mathrm{~h}$. Differences between mean cell number from each set were compared by analysis of variance (ANOVA) test and considered statistically significant at the level of $\mathrm{P}<0.05$.

\section{$3 H$ Thymidine $\left({ }^{\beta} H\right.$ TdR) Uptake Assay}

3HTdR uptake was performed using a modification of the method described previously (Dutta et al., 2012). On the day of the experiment, HEE/HESC cells were incubated with or without various concentrations of $\alpha$-carotene, $\beta$-carotene, or a combination of $\alpha$ - and $\beta$-carotene, respectively, for $20 \mathrm{~h}$ at $37^{\circ} \mathrm{C}$ in a $\mathrm{CO}_{2}$ incubator for different periods of time (Days 1, 3, 5, 7, 9, 11, 15). After $20 \mathrm{~h}, \mathrm{HEE} / \mathrm{HESC}$ cells were incubated with $2 \mathrm{~mm} \mathrm{Ci} /$ well of $3 \mathrm{H} \mathrm{TdR}$ (specific activity $6.7 \mathrm{Ci} / \mathrm{mMol}$ ) for $4 \mathrm{~h}$ at $37^{\circ} \mathrm{C}$ in a $\mathrm{CO}_{2}$ incubator and the reaction was terminated with $1 \mathrm{~mL}$ of $3: 1$ methanol: acetic acid mixture. Subsequently, HEE/HESC cells were washed three times with $80 \%$ methanol, solubilized with $0.5 \mathrm{~mL}$ of $10 \%$ $\mathrm{HCl}$, transferred to scintillation vials, and counted in a beta counter.

\section{Ethics issues}

Institutional review board of Sinai Hospital of Baltimore approved this study.

\section{Results}

Effect of $\alpha$-carotene, $\beta$-carotene, and $\alpha$-plus $\beta$-carotene on HEE cell proliferation

$\alpha$-carotene $(\alpha \mathrm{C}), \beta$-carotene $(\beta \mathrm{C})$, and $\alpha$-plus $\beta$-carotene $(\alpha C+\beta C)$ significantly inhibited the proliferation of HEE cells and significantly increased their doubling time. $(\mathrm{P}<0.05)$ (Figure 1) The inhibitory effect of $\alpha$ - plus $\beta$-carotene $(\alpha \mathrm{C}+\beta \mathrm{C})$ on HEE cell proliferation

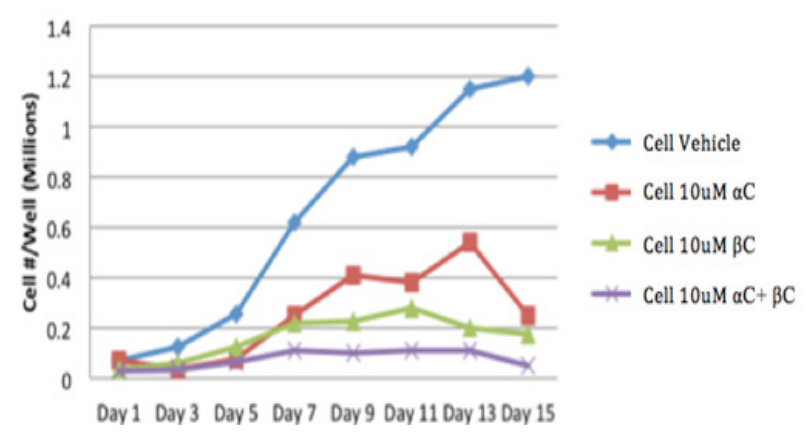

Figure 1: Effect of $\alpha \mathrm{C}$ vs $\beta \mathrm{C}$ vs $\alpha \mathrm{C}+\beta \mathrm{C}$ on proliferation of HEE cells. $\alpha$-carotene $(\alpha \mathrm{C}), \beta$ - carotene $(\beta C)$, and $\alpha$-plus $\beta$-carotene $(\alpha C+\beta C)$ significantly inhibited the proliferation of HEE cells. $(\mathrm{P}<0.05)$ The inhibitory effect of $\alpha$-plus $\beta$-carotene $(\alpha \mathrm{C}+\beta \mathrm{C})$ on HEE cell proliferation was significantly greater than that of $\alpha$-carotene alone, $\beta$-carotene alone, or the cell-vehicle $(\mathrm{P}<0.001)$. 


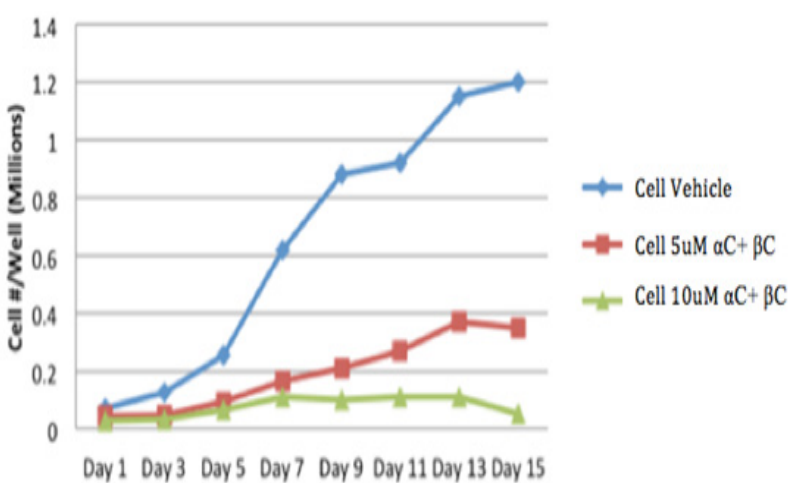

Figure 2. Effect of $\alpha \mathrm{C}+\beta \mathrm{C}$ on Proliferation of HEE Cells at Different Concentrations and at Different Time Points. The inhibitory effect of $10 \mu \mathrm{M} \alpha$-carotene plus $\beta$-carotene on HEE cell proliferation was significantly greater than $5 \mu \mathrm{M} \alpha$-carotene plus $\beta$-carotene, especially at Day 13 and Day $15(\mathrm{P}=0.001)$

was significantly greater than that of $\alpha$-carotene alone, $\beta$-carotene alone, or the cell vehicle $(\mathrm{P}<0.001)$. Furthermore, $\alpha$ - plus $\beta$-carotene significantly inhibited cell proliferation at a lower concentration $(5 \mu \mathrm{M})$ than either carotenoid alone $(10 \mu \mathrm{M})(\mathrm{P}=0.016)$.

In addition, we treated HEE cells with two different concentrations of $\alpha$-plus $\beta$-carotene and measured cell proliferation at different time points. The inhibitory effect of $10 \mu \mathrm{M} \alpha$-carotene plus $\beta$ carotene on HEE cell proliferation was significantly greater than $5 \mu \mathrm{M}$ $\alpha$-carotene plus $\beta$ carotene, especially at Day 13 and Day $15(\mathrm{P}=0.001)$ (Figure 2).

Effects of $\alpha$-carotene, $\beta$-carotene, and $\alpha$-plus $\beta$-carotene on DNA synthesis in HEE cells

HEE cells were treated with different concentrations of $\alpha$-carotene, $\beta$-carotene, or $\alpha$-plus $\beta$-carotene for 20 hours and DNA synthesis was measured by uptake of tritiated thymidine $(3 \mathrm{H} \mathrm{TdR})$. A significant reduction

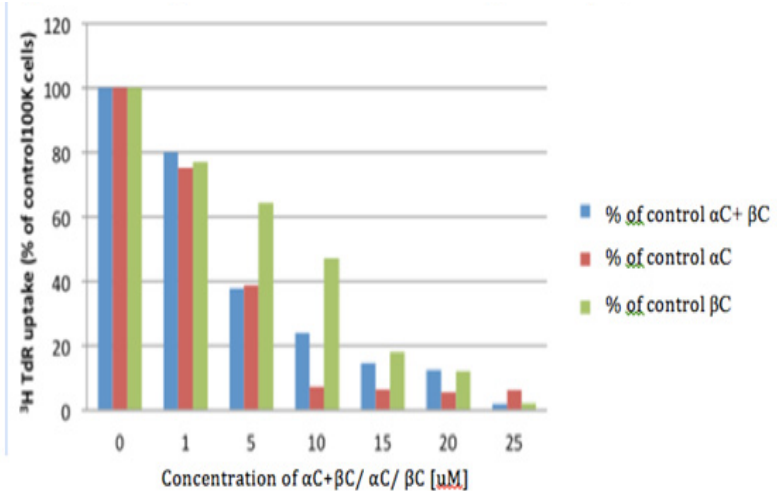

Figure 3. 3HTdR Uptake in HEE Cells with $\alpha \mathrm{C}+\beta \mathrm{C} / \alpha \mathrm{C} /$ $\beta C$. HEE cells were treated with different concentrations of $\alpha$-carotene $(\alpha C), \beta$-carotene $(\beta C)$, or $\alpha$ - plus $\beta$-carotene $(\alpha \mathrm{C}+\beta \mathrm{C})$ and DNA synthesis was measured by uptake of tritiated thymidine (3H TdR). A significant reduction in DNA synthesis was observed with $5 \mu \mathrm{M}$ $\alpha$-carotene, $\beta$-carotene, or $\alpha$ - plus $\beta$ - carotene $(\mathrm{P}<0.05)$. Furthermore, HEE cell DNA synthesis was significantly inhibited by $\alpha$-plus $\beta$-carotene even at a concentration of $1 \mu \mathrm{M}(\mathrm{P}<0.005)$

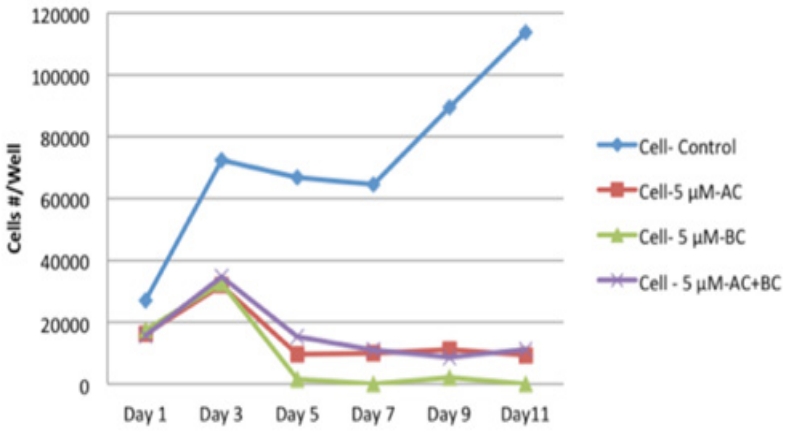

Figure 4. Effect of $\alpha \mathrm{C} / \beta \mathrm{C} / \alpha \mathrm{C}+\beta \mathrm{C}$ on Proliferation of HESC Cells HESC Cells were Treated with Different Concentrations $(1,5,10,15 \mu \mathrm{M})$ of $\alpha$-carotene $(\alpha \mathrm{C})$, $\beta$-carotene $(\beta C)$, or $\alpha$ - plus $\beta$-carotene $(\alpha C+\beta C)$, respectively, for different periods of time (Days 1, 3, $5,7,9,11)$ and cell numbers were determined at each time point. $\alpha$-carotene alone, $\beta$-carotene alone, or $\alpha$ - plus $\beta$ - carotene significantly inhibited the proliferation of HESC cells $(\mathrm{P}<0.005)$.

in DNA synthesis was observed with $5 \mu \mathrm{M} \alpha$-carotene, $\beta$-carotene, or $\alpha$ - plus $\beta$-carotene $(\mathrm{P}<0.05)$. Furthermore, HEE cell DNA synthesis was significantly inhibited by $\alpha$-plus $\beta$-carotene even at a concentration of $1 \mu \mathrm{M}$ $(\mathrm{P}<0.005)$ (Figure 3).

Effect of $\alpha$-carotene, $\beta$-carotene, and $\alpha$-plus $\beta$-carotene on HESC cell proliferation

HESC cells were treated with different concentrations $(1,5,10,15 \mu \mathrm{M})$ of $\alpha$-carotene $(\alpha \mathrm{C}), \beta$ carotene $(\beta \mathrm{C})$, or $\alpha$-plus $\beta$-carotene $(\alpha C+\beta C)$, respectively, for different periods of time (Days 1, 3, 5, 7, 9, 11) and cell numbers were determined at each time point. $\alpha$-carotene alone, $\beta$ carotene alone, or $\alpha$ - plus $\beta$-carotene significantly inhibited the proliferation of HESC cells $(\mathrm{P}<0.005$; Figure 4) resulting in significant prolongation of doubling times.

Effect of $\alpha$-carotene, $\beta$-carotene, and $\alpha$-plus $\beta$-carotene

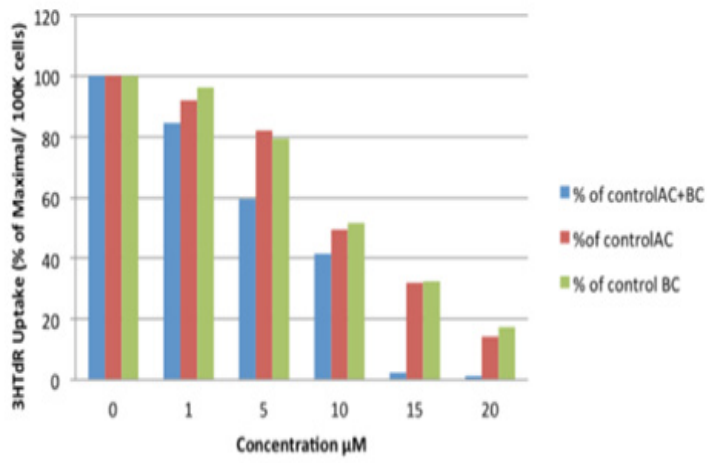

Figure 5. 3HTdR Uptake in HESC Cells with $\alpha \mathrm{C}+\beta \mathrm{C} /$ $\alpha \mathrm{C} / \beta C$ HESC Cells were Treated with Different Concentrations $(1,5,10,15,20 \mu \mathrm{M})$ of $\alpha$-carotene, $\beta$-carotene, or $\alpha$ - plus $\beta$-carotene for 20 hours and DNA synthesis was measured by uptake of tritiated thymidine ( $3 \mathrm{H} \mathrm{TdR})$. A significant decrease in HESC cell DNA synthesis was observed with a low concentration of $5 \mu \mathrm{M} \alpha$-carotene $(\mathrm{P}=0.024)$ and $10 \mu \mathrm{M} \beta$-carotene $(\mathrm{P}=0.007)$. Furthermore, the combination of $\alpha-$ and $\beta$-carotenes significantly inhibited DNA synthesis even at a concentration of $1 \mu \mathrm{M}(\mathrm{p}=0.013)$. 


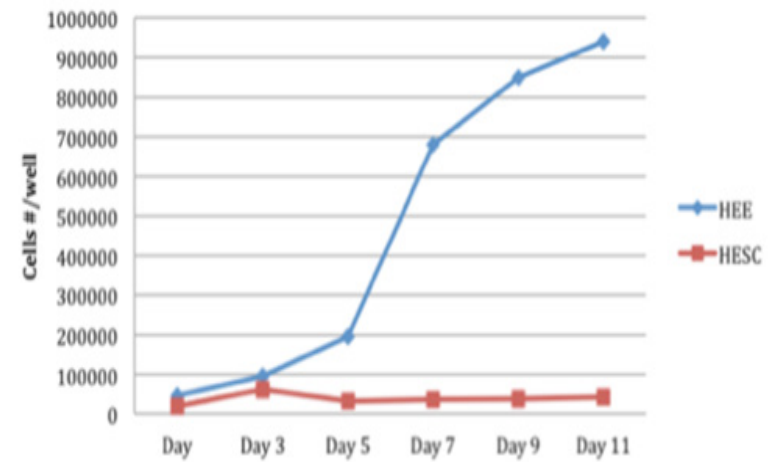

Figure 6. Comparison of Proliferation of HEE Cells and HESC Cells by $\alpha \mathrm{C}+\beta \mathrm{C}$ at $1 \mathrm{uM}$. To define the minimal inhibitory concentration of $\alpha$ - and $\beta$-carotenes, we studied the inhibitory effect of $1 \mathrm{uM} \alpha$ - plus $\beta$-carotene on the proliferation of HEE cells and HESC cells. Cell counts were determined at Days 1, 3, 5, 7, 9, and 11. Interestingly, The $\alpha$ - and $\beta$-carotene combination inhibited the proliferation of HESC cells more than that of HEE cells $(\mathrm{P}=0.009)$.

\section{on DNA synthesis in HESC cells}

HESC cells were treated with different concentrations $(1,5,10,15,20 \mu \mathrm{M})$ of $\alpha$-carotene, $\beta$-carotene, or $\alpha$-plus $\beta$-carotene for 20 hours and DNA synthesis was measured by uptake of tritiated thymidine $(3 \mathrm{H} \mathrm{TdR})$. A significant decrease in HESC cell DNA synthesis was observed with a low concentration of $5 \mu \mathrm{M} \alpha$-carotene $(\mathrm{P}=0.024)$ and $10 \mu \mathrm{M}$ $\beta$-carotene $(\mathrm{P}=0.007)$. Furthermore, the combination of $\alpha$ - and $\beta$-carotenes significantly inhibited DNA synthesis even at a concentration of $1 \mu \mathrm{M}(\mathrm{P}=0.013)$ (Figure 5).

To define the minimal inhibitory concentration of $\alpha$ - and $\beta$-carotenes, we studied the inhibitory effect of $1 \mathrm{uM} \alpha$-plus $\beta$-carotene on the proliferation of HEE cells and HESC cells. HEE and HESC cells were plated at a density of xxx cells per well and treated with $\alpha$ - plus $\beta$-carotene at 24 hours post-plating. Cell counts were determined at Days 1, 3, 5, 7, 9, and 11. Interestingly, The $\alpha$ - and $\beta$-carotene combination inhibited the proliferation of HESC cells more than that of HEE cells $(P=0.009$; Figure 6).

Comparison of DNA Synthesis Inhibition in HEE and HESC Cells Treated with $\alpha$-Plus $\beta$-carotene

HEE and HESC cells were treated with different concentrations of the $\alpha$-plus $\beta$-carotene and DNA synthesis was measured. A greater suppression of DNA synthesis was observed in HEE cells compared to HESC cells, and this effect was statistically significant at a concentration of $10 \mu \mathrm{M}(\mathrm{P}=0.003$; Figure 7$)$.

\section{Discussion}

Our study demonstrates a strong inhibitory effect of $\alpha$ - and $\beta$-carotene on cellular proliferation and DNA synthesis of normal human esophageal epithelial cells (HEE cells) and human esophageal squamous cell cancer cells (HESC cells) in in-vitro monolayer culture. This system allows us to elucidate the role of various therapeutic agents in prevention and treatment of esophageal cancer.

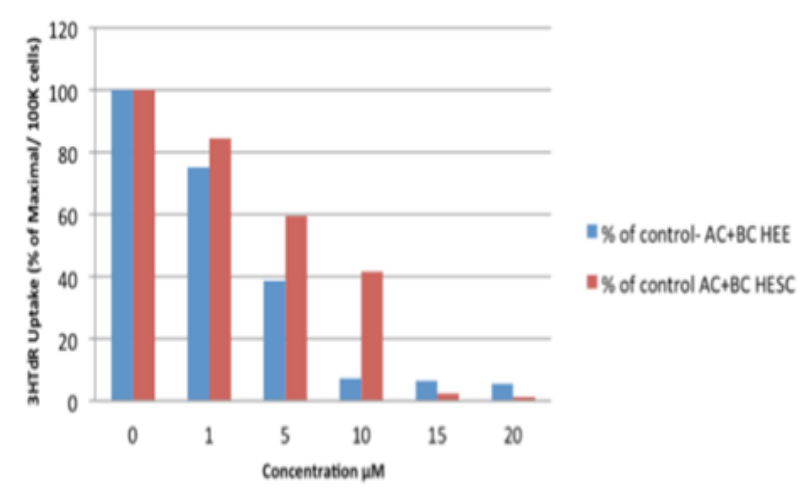

Figure 7. Comparison between 3HTdR Uptake in HEE and HESC Cells by $\alpha \mathrm{C}+\beta \mathrm{C}$. HEE and HESC Cells were Treated with Different Concentrations of the $\alpha$ - plus $\beta$-carotene and DNA Synthesis was Measured. A greater suppression of DNA synthesis was observed in HEE cells compared to HESC cells, and this effect was statistically significant at a concentration of $10 \mu \mathrm{M}(\mathrm{p}=0.003)$.

Most of the studies in the past have evaluated an effect of the carotenoids over isolated cultured human esophageal squamous cell cancer line (HESC). However in our study, we examined the effect of carotenoids on the proliferation of normal human esophageal epithelial cells (HEE cells). To date this is the first report of successful culture of HEE cells from human mucosal transplants. Inhibition of cellular proliferation in HEE cells may serve as a model for various intervention therapies for prevention of transformation of normal esophageal mucosal cells to pre-malignant or malignant cells.

It is noteworthy that there was greater magnitude of inhibition of DNA synthesis in HEE cells than HESC cells. There was significant reduction in DNA synthesis with $\alpha$-carotene $(5 \mathrm{uM})$ as well as b-carotene $(5 \mathrm{uM})$ in HEE cells. This may have a likely clinical significance in that carotenoids may be effective when applied early in the course of the disease i.e. Barret's esophagus. In fact we have previously demonstrated in our study that $\beta$-carotene therapy reduced the mean length of Barret's segment and also caused restoration of histological and molecular changes in esophageal mucosa of patients with Barret's esophagus (Dutta et al., 2012). Thus, by targeting the HEE cells, carotenes may serve as an important preventive modality for esophageal cancer.

A few animal studies have shown that $\alpha$-carotene possesses higher activity than $\beta$-carotene in suppressing carcinogenesis in lung, liver, skin and colon cells (Murakoshi et al., 1992; Narisawa et al., 1996). Although, there have been studies done on the role of $\beta$-carotene over human esophageal squamous cancer cells, but to the best of our knowledge, there has not been any study evaluating the role of $\alpha$-carotene over human esophageal squamous cell cancer lines in-vitro. Our data suggests that the minimum concentration required for significant inhibition of DNA synthesis was lower for $\alpha$ - carotene compared to $\beta$ - carotene $(5 \mathrm{uM}$ vs $10 \mathrm{uM})$ in human esophageal squamous cancer cells (HESC cells). However, the minimum concentration required for inhibition of DNA 
synthesis in HEE cells was similar for both $\alpha$ - and $\beta$-carotenes. Considering the significant inhibition of cellular proliferation of human esophageal cancer cells by a-carotene at a lower concentration, additional studies are needed to elucidate the role of $\alpha$-carotenoids as prophylactic as well as therapeutic agents in esophageal carcinogenesis in human trials and animal studies.

Interestingly, we also noted the synergistic effect of carotenoids, $\alpha$ - and $\beta$-carotene together on cell proliferation and DNA synthesis in HESC cells. Our data suggests that HEE and HESC cell DNA synthesis was significantly inhibited even at a concentration of 1uM. Shao-Kang (2012) showed the synergistic effect of $\beta$-carotene and 1,25 - dihydroxyvitamin $\mathrm{D}_{3}$ on human esophageal squamous cancer EC9706 cells whereas Zhang (2016) used b-carotene and 5-Fluorouracil in the same cell line to demonstrate synergism. Our study is different because it is for the first time that the effect of $\alpha$ - carotene has been studied in combination with $\beta$-carotene over HEE and HESC cells. In the study by Wang et al, the minimum concentration of $\beta$-carotene required for significant inhibition of cell proliferation of EC9706 cells was 40uM whereas in our study the minimum concentration of $\beta$-carotene required was $10 \mathrm{uM}$ for significant reduction in cell proliferation. At higher doses, $\beta$-carotene has been reported to cause decreased mitochondrial function in human K562 erythroleukemic and 28SV4 retinal pigment epithelial cells by an unidentified mechanism but clinical trials evaluating the toxic effects of $\beta$-carotenes in humans are lacking (Hurst et al., 2005). The synergism is beneficial because it would enable a lower dose of $\beta$-carotene to be used for protection against esophageal malignancy.

The molecular mechanism of carotenoids in isolated human cell culture has been studied in some details. These studies have shown that carotenoids exert their protective effect through following mechanisms: 1) causing cell cycle arrest in $\mathrm{G} 1 / \mathrm{G} 0$ phase by down-regulating the levels of Cyclin D1 (Malumbres et al., 2009); 2) induction of apoptosis by down-regulating the levels of Survivin (Kato et al., 2001; Zhu et al., 2016); 3) enhanced cellular gap junction communication (Bertram et al., 2004) and 4 ) anti-angiogenic effect through modulation of various cytokines (decreased levels of IL-6, IL-1b, TNF-a, and GM-CSF and increased level of IL-2 and TIMP-1) (Guruvayoorappan et al., 2007). We did not study the mechanism of cellular inhibition and induction of DNA damage by carotenoids in our cell cycle. Additional studies are needed to illustrate the mechanism of DNA damage by carotenoids.

In conclusion, our study demonstrated that the $\alpha$-carotene and $\beta$-carotene alone or in combination inhibit the proliferation and DNA synthesis of both HEE and HESC cells. Furthermore, a-carotene is more effective than $\beta$-carotene in HESC cell inhibition. Additional animal and well-designed human studies are needed to examine the beneficial effect of carotenoids in inhibiting the process of neoplastic transformation and carcinogenesis in esophageal and upper aero digestive tract cancer.

\section{References}

Al-Wadei HA, Schuller HM (2009). Non-genomic inhibitory signaling of beta-carotene in squamous cell carcinoma of the lungs. Int J Oncol, 34, 1093-8.

Bertram JS (2004). Dietary carotenoids, connexins and cancer: what is the connection?. Biochem Soc Trans, 32, 985-9.

Dutta SK, Agrawal K, Girotra M, et al (2012). Barrett's esophagus and $\beta$-carotene therapy: symptomatic improvement in GERD and enhanced HSP70 expression in esophageal mucosa. Asian Pac J Cancer Prev, 13, 6011-6.

Ellis BC, Gattoni-Celli S, Mancia A, Kindy MS (2009). The vitamin D3 transcriptomic response in skin cells derived from the Atlantic bottlenose dolphin. Dev Comp Immunol, 33, 901-12.

Freedman ND, Abnet CC, Leitzmann MF, et al (2007). A prospective study of tobacco, alcohol, and the risk of esophageal and gastric cancer subtypes. Am J Epidemiol, 165, 1424-33.

Garewal HS (1993). Beta-carotene and vitamin E in oral cancer prevention. J Cell Biochem Suppl, 17, 262-9.

Ge XX, Xing MY, Yu LF, Shen P (2013). Carotenoid Intake and Esophageal Cancer Risk: a Meta-analysis. Asian Pac J Cancer Prev, 14, 1911-8.

Gholipour C, Shalchi RA, Abbasi M (2008). A histopathological study of esophageal cancer on the western side of the Casian Littoral from 1994 to 2003. Dis Esophagus, 21, 322.

Glade MJ (1999). Food, nutrition, and the prevention of cancer: a global perspective. American Institute for Cancer Research/ World Cancer Research Fund, American Institute for Cancer Research, 1997. Nutrition, 15, 523-6.

Greenberg ER, Baron JA, Stukel TA, et al (1990). A clinical trial of Beta Carotene to prevent basal-cell and squamous-cell cancers of the skin. $N$ Engl J Med, 323, 789-95.

Greenwald P (2003). $\beta$-Carotene and lung cancer: A lesson for future chemoprevention investigations?. J Natl Cancer Inst, 95, e1.

Guruvayoorappan C, Kuttan G (2007). Beta-carotene inhibits tumor-specific angiogenesis by altering the cytokine profile and inhibits the nuclear translocation of transcription factors in B16F-10 melanoma cells. Integr Cancer Ther, 6, 258-70.

Hurst JS, Saini MK, Jin G-F, Awasthi YC, van Kuijk FJ (2005). Toxicity of oxidized beta-carotene to cultured human cells. Exp Eye Res, 81, 239-43.

Kamangar F, Dores GM, Anderson WF (2006). Patterns of cancer incidence, mortality, and prevalence across five continents: defining priorities to reduce cancer disparities in different geographic regions of the world. J Clin Oncol, 24, 2137-50.

Kato J, Kuwabara Y, Mitani M, et al (2001). Expression of survivin in esophageal cancer: correlation with the prognosis and response to chemotherapy. Int J Cancer, 95, 92-5.

Malumbres M, Barbacid M (2009). Cell cycle, CDKs and cancer: a changing paradigm. Nat Rev Cancer, 9, 153-66.

Mayne ST, Cartmel B, Baum M, et al (2001). Randomized trial of supplemental beta-carotene to prevent second head and neck cancer. Cancer Res, 61, 1457-63.

Murakoshi M, Nishino H, Satomi Y, et al (1992). Potent preventive action of $\beta$ - carotene against carcinogenesis: Spontaneous liver carcinogenesis and promoting stage of lung and skin carcinogenesis in mice are suppressed more effectively by $\alpha$-carotene than by $\beta$-carotene. Cancer Res, 52, 6583-7.

Narisawa T, Fukaura Y, Hasebe M, et al (1996). Inhibitory effects of natural carotenoids, $\alpha$-carotene, $\beta$-carotene, lycopene and lutein, on colonic aberrant crypt foci formation in rats. Cancer Lett, 107, 137-42.

Peto R, Doll R, Buckley JD, Sporn MB (1981). Can dietary 
beta-carotene materially reduce human cancer rates?. Nature, 290, 201-8.

Resau JH, Phelps PC, Zhu SM, et al (1990). Long-term culture of human esophageal explants and cells. Cytotechnology, 3, 61-73.

Ruol A, Castoro C, Portale G, et al (2009). Trends in management and prognosis for esophageal cancer surgery: twenty-five years of experience at a single institution. Arch Surg, 144, 247-54.

Sacha T, Zawada M, Dulinska-Litewka J, et al (2011). Beta carotene regulates the expression of proapoptotic BAX and CAPN2 in HL-60, U-937 and TF-1 - human acute myeloid leukemia cell lines; microarray, RQ-PCR and Western Blot analysis. Przegl Lek, 68, 258-62.

Sampaio AR, Chagas CE, Ong TP, Moreno FS (2007). Vitamin $A$ and $\beta$-carotene inhibitory effect during 1 , 2-dimethylhydrazine induced hepatocarcinogenesis potentiated by 5-azacytidine. Food Chem Toxicol, 45, 563-7.

Siegel RL, Miller KD, Jemal A (2017). Cancer statistics, 2017. CA Cancer J Clin, 67, 7.

Stefani ED, Deneo-Pellegrini H, Ronco AL, et al (2012). Meat consumption, cooking methods, mutagens, and risk of squamous cell carcinoma of the esophagus: a case-control study in Uruguay. Nutr Cancer, 64, 294-9.

Wang SK, Yang L, Wang TT, et al (2012). Inhibition of proliferation and apoptosis of EC9706 cells treated with $\beta$-carotene and 1,25-dihydroxyvitamin D3 in combination. Asian Pa J Cancer Prev, 13, 6327-32.

Zhang Y, Zhu X, Huang T, et al (2016). $\beta$-Carotene synergistically enhances the anti-tumor effect of 5-fluorouracil on esophageal squamous cell carcinoma in vivo and in vitro. Toxicol Lett, 261, 49-58.

Zhu X, Zhang Y, Li Q, et al (2016). $\beta$-Carotene induces apoptosis in human esophageal squamous cell carcinoma cell lines via the Cav-1/AKT/NF-kB signaling pathway. $J$ Biochem Mol Toxicol, 30, 148-57.

This work is licensed under a Creative Commons AttributionNon Commercial 4.0 International License. 